\title{
Challenges for information literacy education at a university of technology
}

\section{Genevieve Hart and Marion Davids}

\begin{abstract}
The article reports on an action research project to investigate the effectiveness of an information literacy intervention for first year engineering students at the Cape Peninsula University of Technology (CPUT). The intervention consisted of two workshops which aimed to teach the students to find information relevant to their essays via the university's OPAC and engineering databases and to reference and cite their sources. The project assessed students' information skills before and after the two workshops with the use of a questionnaire consisting of a set of questions based on some of the American College and Research Library (ACRL) standards. The research provides insight into how information literacy education at CPUT library can be improved. Its major recommendations are that more time in the timetable must be allocated to information literacy education and that lecturers should recognise the educational role of librarians.
\end{abstract}

Key words: Information literacy education; Engineering education; Cape Peninsula University of Technology; Library and faculty collaboration

\section{Introduction}

This article reports on an action research project that investigated the effectiveness of an information literacy education intervention in the Engineering Faculty of the Cape Peninsula University of Technology (CPUT). Information literacy education develops life-long learning skills which not only support students' tertiary studies but also empower them in their future careers in industry. The purpose of action research is to improve day to day practices in the workplace or classroom (Powell 1997: 45) and it was hoped that assessing the information literacy intervention might provide insights not only for CPUT Library but for other academic libraries and for engineering educators.

From the late 1990s, South African higher education institutions (HEIs) have been engaged in curriculum reform to bring their academic programmes in line with the National Qualifications Framework of the South African Qualifications Authority (SAQA). SAQA lists information literacy as a cross-field critical outcome. Information literacy education is generally accepted as part of the mission of academic librarians; but they need to build a body of research evidence to underpin their practice. 


\section{Rationale and background}

The vision of CPUT is "to be at the heart of technology and education and innovation in Africa" (2005). Its mission is "to develop and sustain an empowering environment where, through teaching, learning, research and scholarship, our students and staff, in partnership with the community and industry, are able to create and apply knowledge that contributes to development" (2006). CPUT Library sees itself as a key role-player in the "empowering environment" referred to in the mission statement. The phrase "create and apply knowledge that contributes to development" underlies the information literacy programmes run by the Library.

The Library's information literacy programming at CPUT faces challenges specific to its position in the new higher education landscape. CPUT is the outcome of the merger of two technikons in 2005 -the Cape Technikon and the Peninsula Technikon. The so-called "size and shape" restructuring process between 1999 and 2005 reduced numbers of higher education institutions from 36 to 25 and categorised them into three groups: universities of technology, comprehensive universities and traditional. The five South African universities of technology replaced the technikons, which had replaced the CATES (Colleges for Advanced Technical Education) in the late 1970s. The change represents more than a mere name change. The universities of technology still would claim to provide an education more closely applicable to the workplace than traditional universities but they are expected to take on the responsibilities of universities and change their image as "glorified high schools" (Masermule2005; Du Pré 2009: 60). This has implications for their curricula and pedagogies - and libraries.

The mergers hoped to overcome apartheid-era disparities by cutting across historical divides but Du Pré (2009: 16) argues that the mergers in fact hampered the progress of the UoT sector as many UoTs had new issues thrust upon them. One challenge is the scattered and unevenly resourced campuses of the merged UoTs. This comment might well apply to CPUT and its library services. Its library is spread across eight campuses and, for the last few years, restructuring has been the priority. An information literacy task team was established in 2005 to implement a programme across faculties but with the merging of the two technikons this project was only put into action in 2009.

\section{Information literacy education}

The notion of information literacy emerged in the 1970s with the rise of new information technologies. Sayed defines information literacy as the lifelong ability to access sources of information, locate information and critically evaluate information, not only in the academic environment but also on the work and home fronts (1998: 1). The recent LIS Transformation Charter of the National Council for Library and Information Services identifies information literacy education as a priority for university libraries, pointing out that the first baseline study of employers' expectations of graduates conducted by the oversight body Higher Education South 
Africa in 2007 reported widespread concern that graduates lack the ability to find and use information (2009: 31).

The Engineering Council of South Africa (2004: 4) sees problem solving as a crucial learning outcome. Students are expected to demonstrate competence in identifying, assessing, formulating and solving engineering problems creatively and innovatively. The preface to the Information Literacy Standards for Science and Engineering /Technology (ALA/ACRL/STS Task Team ...2006) states that information literacy is vital for students of engineering who must access a wide variety of information sources that carry the body of knowledge in their discipline. Writing in the context of professional engineering education in Australia, Roberts and Bhatt (2007: 244) assert that "the ability to access, evaluate and synthesise high-quality research material is the backbone of critical thinking in academic and professional contexts for engineers and industrial designers". Yet there is comment in the literature that engineering educators tend to underestimate the value of libraries' information literacy programmes. An example is the study in the Engineering Faculty at a Canadian university that found that most lecturing staff thought that library instruction was not necessary even though $41 \%$ indicated that some or all of their courses in the first and second year required library research (Leckie \& Fullerton 1999).

The ACRL Information Literacy Competency Standards for Higher Education (2000) identify five standards and twenty-five performance indicators for information literacy, which underpin the later standards for science and engineering. The five standards state that the information literate student:

- determines the nature and extent of the information needed

- accesses needed information effectively and efficiently

- evaluates information and its sources critically and incorporates selected information into his or her knowledge base

- uses information effectively to accomplish a specific purpose

- understands the economic, legal, and social issues surrounding the use of information and accesses and uses information ethically and legally.

There are several information literacy models that can frame the teaching of the competencies listed by ACRL. Kuhlthau's Information Search Model (ISP), for example, describes information seeking as a sense-making learning process of different phases each with its own strategies (2004). The outcome of years of research, the model has been tested by researchers across the world and found to apply in a variety of contexts, including online environments (Kuhlthau, Heinström \& Todd 2008). Kuhlthau assumes that the purpose of a library's information literacy education is to develop students' insight into the process of information handling and into how each of its phases connects. This clearly cannot be achieved in once-off workshops; rather a programme or series of workshops, perhaps accompanying a project, is implied. 


\section{Research in information literacy in higher education}

The review of research reveals certain key issues for information literacy education at tertiary level. These include:

- the under-preparedness of students for university education

- the need for collaboration between librarians and faculty

- challenges in assessing information literacy programmes

- the challenges and opportunities of information and communication technologies.

A major theme in the South African information literacy literature is the underpreparedness of students for the demands of university education. They lack reading/writing and information-handling skills (for example Feldmann \& Feldmann 2000; Rademeyer 2001; Hugo 2003; Van Wyk 2002; King 2007). In 1998, CALICO, the Western Cape's higher education library consortium, assessed the competence of students in the five higher education institutions of the region in three areas of information literacy: reading and writing ability, library usage and computer competence. The study found significant differences between students from the historically advantaged campuses and those from the historically disadvantaged University of the Western Cape and Peninsula Technikon (Sayed 1999). De Jager and Nassimbeni's survey of university libraries in 2002 echoes this finding and suggests that information literacy programmes should take account of the previous experiences that may either hinder or enhance students' learning (2003: 114).

Information skills are best learned and practised as students undertake their "real" work, which implies the need for collaboration between library and faculty (McGuiness 2006: 573; Young 2008: 139). Research indicates that a successful information literacy programme must be introduced early and be reinforced often, with assignments of increasing complexity. However, academics' lack of recognition of the need for information literacy education presents a challenge, which might be exacerbated by online delivery of courses (Gurney \& Wilkes 2008: 27; Russell 2009). Many academics just assume that students have already acquired information literacy skills before arriving at university. King (2007: 77) argues that students will not devote time to activities which do not count towards their official assessment; yet, finding a foothold in accredited programmes is a challenge for information literacy educators.

"Assessment" refers also to the evaluation of programmes which provides evidence for their improvement (Yu, Sullivan \& Woodall 2006). According to the ACRL (2000), an assessment programme should be designed by both academics and librarians, pinpoint areas for further development, and build on learning goals already achieved. Again, much depends on how the information literacy education is positioned in the curriculum. Responses in 2003 to De Jager and Nassimbeni's survey of information literacy programmes in South African universities presents some evidence of growing awareness of the need for careful assessment. 
All agree that computer literacy is an important component of information literacy. As libraries and courses are increasingly digitised, students need to be able to access and navigate online resources successfully. Computer literacy instruction is not the norm in South African schools and the skills of incoming students range from highly proficient to non-existent (Hugo 2003; Oberprieler, Masters \& Gibbs 2005). Learning how to "access" information implies critical thinking skills as much as technical proficiency. Even ICT-savvy, so-called "Generation Y", university entrants cannot be assumed to be savvy information seekers. Studies across the world provide evidence that most students' first choice in information-seeking is the Internet (for example Connaway \& Dickey 2010). At the same time, there is growing evidence that reliance on Internet sources affects negatively the quality of student writing (Radia \& Stapleton 2007: 9). Students understandably like the convenience of the Internet but are often unable to evaluate the credibility of its sources (Somi \& De Jager 2005).

The shifts to e-teaching in higher education bring both risks and opportunities for information literacy education. Delivering information literacy tuition via the library's website might be cost effective; however, there is concern that online courses might aggravate the bypassing of the academic library that was referred to earlier. Reading lists, online resources and access to the library's website might be provided in the "one-stop shop" of a virtual course but some research reveals a neglect of what Gurney and Wilkes call "instructional information literacy guidance" (2008: 27).

\section{Research methodology}

The research investigated information literacy skills of first year mechanical engineering students at CPUT and assessed the effectiveness of the researcher's existing information literacy teaching, with a view to identifying its weaknesses and making recommendations to the Library and to the Engineering Faculty at CPUT. The two fundamental questions that the project hoped to answer were:

- Is the researcher's information literacy intervention of two 90-minute workshops in the first year engineering programme effective?

- How should information literacy programmes be delivered?

More specific questions, directly related to the ACRL standards chosen for the workshops, were also identified, for example:

- Do the workshops teach students how to analyse their information needs?

- Do they teach students how to find relevant information through searching the OPAC and the library's databases?

- Does the course result in an increase in the use of high-quality resources in the essay that is part of the engineering course and in good citing and referencing?

The last research question assumed access to the students' assignments - as agreed to by the lecturer before the project began. However, she withdrew her permission some weeks into the semester, citing concern over the ethics of allowing a third party to read the essays. The withdrawal will be returned to. 
The test questions in the pre-and post- workshop questionnaire rely on the ACRL standards and performance indicators, which are well tested and accepted as reliable benchmarks of information literacy. The questionnaire was completed ahead of time by 26 librarians at CPUT who were deemed able to assess its validity. The research was conducted with 129 engineering students at the Cape Town campus of CPUT- all enrolled for the same course. Students were informed of the project and asked to sign consent forms before completing a pre-intervention test a few days prior to receiving instruction in two workshops in class time. After instruction, students completed the same test and were also asked to assess the two workshops. The difference between the pre- and post- intervention test scores should indicate the success of the workshops (Powell 1997: 41).

The workshops aimed at teaching skills useful for the writing assignment and building confidence in students when they approach CPUT's electronic resources and databases. The two 90 minute workshops were run by the researcher and a librarian colleague and included hands-on practice. They covered the library's OPAC, the library's electronic databases, Science Direct, Engineering Village and EbscoHost, and referencing techniques. The first workshop included a take-home exercise. Its purpose was to reinforce the workshop learning and to prepare students for their essay.

\section{Findings}

Tables 1 and 2 summarise the data on students' personal backgrounds and experience of computers, libraries and reading. As mentioned earlier, previous research suggests that these might be significant factors in the preparedness of university entrants for their writing assignments. The 129 students were a diverse group with Xhosaspeaking students making up $33 \%$ and Afrikaans and English mother tongue languages $24 \%$ and $21 \%$ respectively. A large majority were males ( $83 \%)$.

\begin{tabular}{|l|l|l|}
\hline & Yes & No \\
\hline $\begin{array}{l}\text { Prior computer skills training at school or } \\
\text { elsewhere? }\end{array}$ & $51 \%$ & $49 \%$ \\
\hline Access to a computer at home? & $68 \%$ & $38 \%$ \\
\hline Do you use email? & $78 \%$ & $22 \%$ \\
\hline $\begin{array}{l}\text { Which of the following ICT facilities have you } \\
\text { used in the last month? }\end{array}$ & & \\
\hline CPUT's Learning commons & $79 \%$ & \\
\hline Friend's PC & $32 \%$ & \\
\hline Internet café & $22 \%$ & \\
\hline PC at home & $47 \%$ & \\
\hline
\end{tabular}

Table 1: Computer experience

Overall, the responses to the series of questions on ICT use and access indicate that it cannot be assumed that South African students - or at least those enrolled for 
engineering courses - do not have access to ICT. Table 1 highlights the importance of CPUT's computer rooms.

\begin{tabular}{|l|l|l|}
\hline Do you ever buy books? & Yes & No \\
\hline $\begin{array}{l}\text { Did you have access to a school library where } \\
\text { you could borrow books? }\end{array}$ & $61 \%$ & $39 \%$ \\
\hline $\begin{array}{l}\text { Have you borrowed books from the public } \\
\text { library in the past three months? }\end{array}$ & $33 \%$ & $67 \%$ \\
\hline
\end{tabular}

Table 2: Access to books and libraries

On being asked what they have read in the last month, $81 \%$ reply magazines, $73 \%$ newspapers, $69 \%$ websites and $51 \%$ books. The figure of $67 \%$ who claim to have had access to school libraries is surprising, given the low number of school libraries in South Africa (LIS Transformation Charter 2009). It is a pity that the questionnaire did not ask which schools participants had attended. The significance of the figures provided in Tables 1 and 2 will be returned to later once the test scores have been reported.

\section{Information skills assessment}

The next section of the questionnaire tested students' information skills - before and after the two workshops. Five sets of skills were tested:

- Formulating a search statement- for example choosing key words, using Boolean operators

- Knowing various types of documents such as books and serials and when to use which

- Using the OPAC to find materials in the library and using the information contained in a catalogue entry

- Using bibliographic and full-text databases to find journal articles, understanding the information in their entries, using abstracts to select relevant articles

- Using information ethically and legally- citing procedures and avoiding plagiarism.

It would take up too much space to provide the scores for each of the 13 questions. The first key finding is that participants are in clear need of information literacy education with their average score in the first test being only $40 \%$.

The analysis of student responses in the post-test shows an improvement in scores across all questions. Figure 1 shows the difference between the pre-and postintervention scores to be on average 21\%. Eight students did not improve their scores but one student increased his mark by $61 \%$ and another by $47 \%$. The median score is $40 \%$ for the pre-intervention test and $60 \%$ for the post-intervention test. 


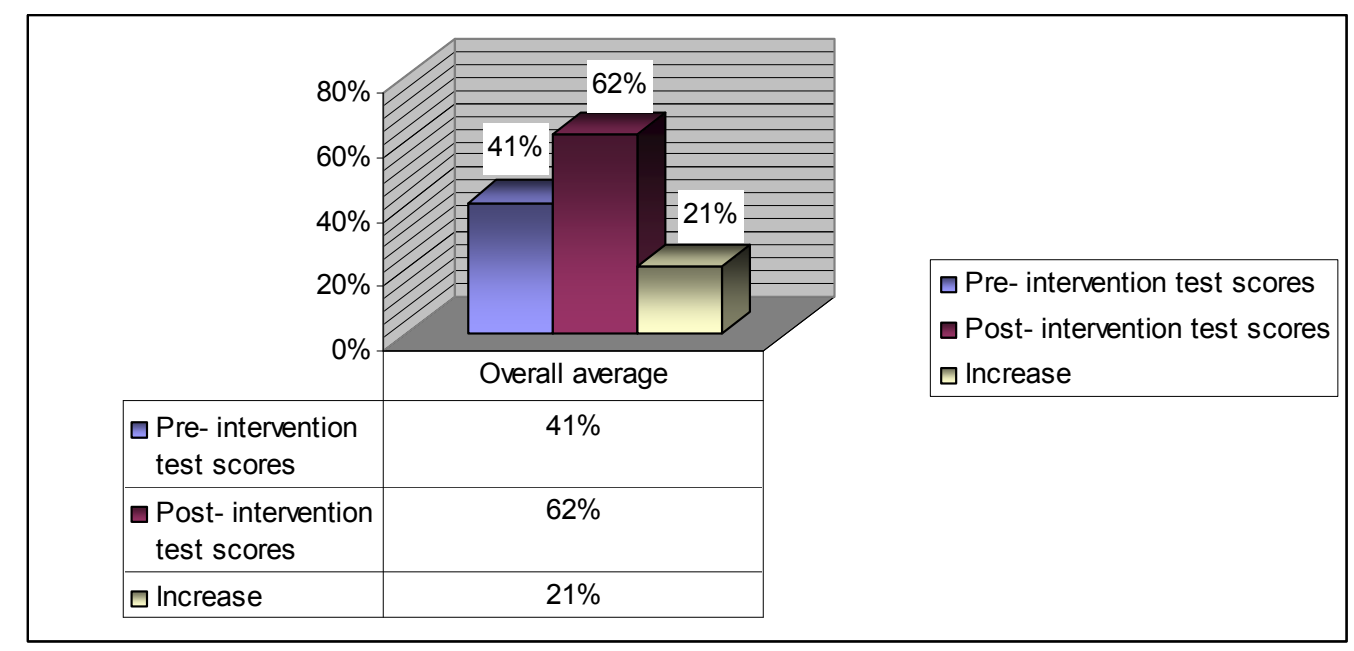

Figure 1: Pre-and post- test scores

A t-test for matched pairs was carried out on the pre-and post test scores giving a result of $t=19.67$ (128df), which shows a highly significant increase $(p<0.000001)$. The non-parametric Wilcoxon matched pairs test gave a similar result $(\mathrm{p}<0.000001)$.

Results in some questions raise questions. For example, the score for the questions on Boolean searching and truncating increased by only 12\%. Hutcherson (2004: 353) warns that many of librarians' commonly used terms, such as truncation, tend to be dismissed as library jargon.

Cross tabulation of scores with some of the preliminary questions was performed to explore possible connections. Figure 2 provides an analysis of before and after scores by language group. It shows that the scores of all language groups improved. Afrikaans-speaking students fared better in both the pre-intervention test and the post-intervention test than students with another language as a mother tongue. It is beyond the scope of the study to investigate why Xhosa-speaking students performed less well than Afrikaans and English speaking but it probably is related to school background.

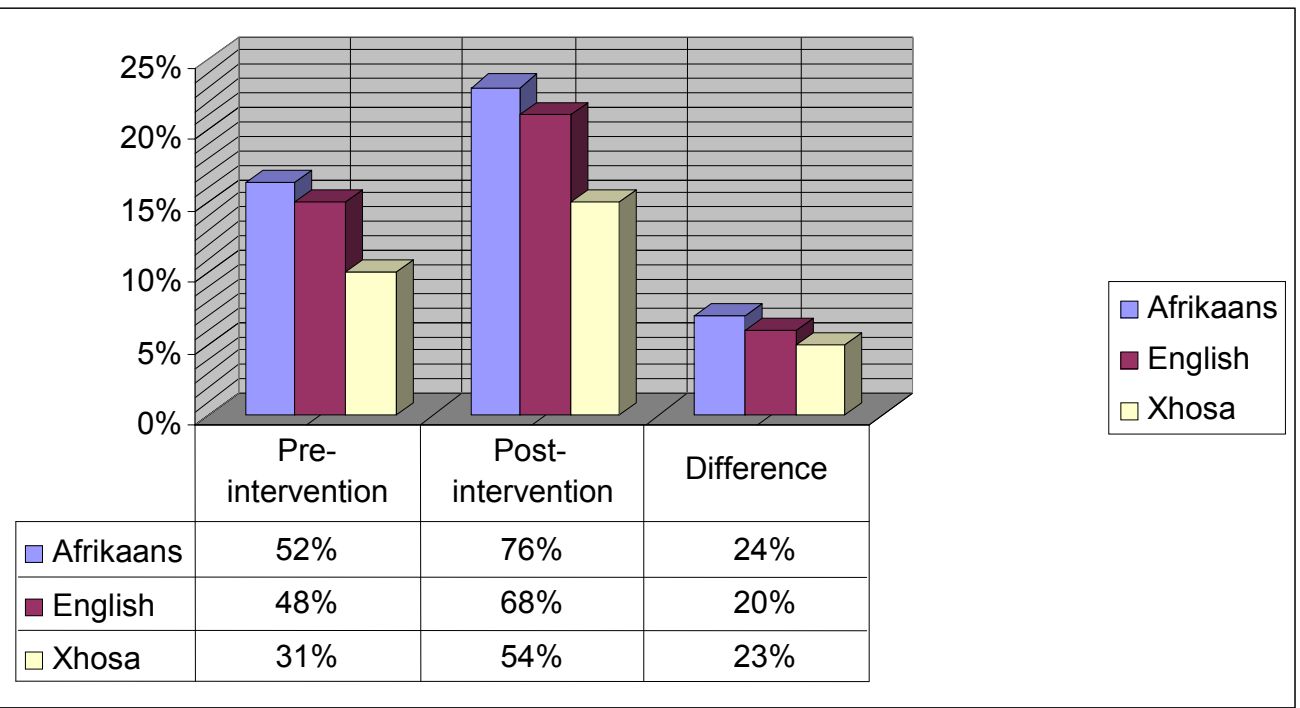


Figure 2: Average performances by English, Afrikaans and Xhosa mother tongue language

One of the questions in the literature is the connection between computer literacy and information literacy. A comparison of the test scores of students who had received prior formal computer literacy education and those who had not indicates a difference in the average scores of $7 \%$.

Reading habits, use of public libraries and book buying seem to have no marked impact on scores. However, access to a school library might well be connected to performance. Students from schools with libraries score an average of $45 \%$ for the pre-intervention test score and 65\% in the post intervention test, as opposed to $37 \%$ and $58 \%$ of those without access to school libraries. Of course it might not be just the existence of a school library in their education that makes a difference to students' information literacy. In South Africa, as the LIS Transformation Charter (2009) points out, schools with libraries are the well-resourced suburban schools.

\section{Students' perceptions of the information literacy education intervention}

Table 3 summarises students' responses to the assessment form handed out after the workshop. The claims that the training was useful and provided life-long skills are encouraging. However, the 36 negative replies to the question on whether they could use the databases on their own indicate a need for more extensive training.

\begin{tabular}{|l|l|l|}
\hline & Yes & No \\
\hline 1. Did you find the training useful? & 112 & 17 \\
\hline 2. Would you be able to use the databases on your own? & 93 & 36 \\
\hline $\begin{array}{l}\text { 3. Did the presenter make the training understandable to } \\
\text { you? }\end{array}$ & 102 & 27 \\
\hline $\begin{array}{l}\text { 4. Can you apply what you have learned as a life-long } \\
\text { skill? }\end{array}$ & 111 & 18 \\
\hline
\end{tabular}

\section{Table 3: Students' evaluation of database training}

Students were then asked two open-ended questions:

- What did you like about the training session?

- Was there anything you did not like about the training session?

Table 4 categorises their responses to the first question and gives selected quotations in support. The positive comments are often quite specific to the desired learning outcomes of the intervention, providing evidence in support of the test scores.

\begin{tabular}{|lr|l|}
\hline $\begin{array}{l}\text { Units } \\
\text { meaning }\end{array}$ & of & Examples of responses \\
\hline $\begin{array}{l}\text { Learning new } \\
\text { things }\end{array}$ & $\begin{array}{l}\text { "A very informative session, providing a step by step explanation } \\
\text { which made it very easy to understand". } \\
\text { "I like the sound of the word "credible information'... I now know } \\
\text { the difference. I will definitely apply the searching skills". }\end{array}$ \\
\hline \\
httpS://repOSitory.UWC.aC.Za/
\end{tabular}




\begin{tabular}{|c|c|}
\hline $\begin{array}{ll}\text { Useful } & \text { for } \\
\text { assignment } & \\
\text { writing } & \end{array}$ & $\begin{array}{l}\text { "I have learnt how to search the catalogue and the databases". } \\
\text { "Helpful. I understand now how to do research". }\end{array}$ \\
\hline $\begin{array}{l}\text { Individual } \\
\text { attention }\end{array}$ & "I received individual attention" \\
\hline $\begin{array}{l}\text { Hands-on } \\
\text { training }\end{array}$ & $\begin{array}{l}\text { "I like the fact that we had to do all the exercises ourselves so that we } \\
\text { understand it better". }\end{array}$ \\
\hline $\begin{array}{l}\text { Specific } \\
\text { information } \\
\text { skills }\end{array}$ & $\begin{array}{l}\text { "She gave nice examples of how to use the Harvard referencing } \\
\text { method" } \\
\text { " "The database training was amazing". } \\
\text { "One can find a wide variety of sources on the CPUT homepage } \\
\text { (databases)". } \\
\text { "I now know more about plagiarism and citing" } \\
\text { "Gaining new knowledge and the easy way of searching for journals. } \\
\text { I liked the session on plagiarism" }\end{array}$ \\
\hline Presenter's style & $\begin{array}{l}\text { "Lovely, enthusiastic teacher. Useful and relevant notes for } \\
\text { engineering students". } \\
\text { "The fact that she is passionate about the topic of information } \\
\text { literacy and database searching made it interesting". }\end{array}$ \\
\hline
\end{tabular}

Table 4: What did you like about the workshops?

Negative comment included complaints over the lack of time to complete the various activities in the workshops. They indicate that information literacy education needs a stronger place in the academic programme.

\section{Reflections on the findings}

The project identifies the lack of information skills among first year CPUT students, which indicates that the need for instruction from librarians is real. The study thus supports earlier research findings in other contexts. The "highly significant" improvement in scores indicates that the workshops on the whole met the desired learning outcomes. The major limitation comes from the lack of access to students' assignments. The before-and after- quizzes measure immediate learning; but examining the citations in the assignments would have shown if students were able to transfer their learning from the workshops. This would have shown if they had gained insight into and control of the information seeking process - an essential attribute of information literacy, according to its chief theorists like Kuhlthau (2004).

Another purpose of the study was to examine if background factors such as home language and computer literacy impact on information literacy programmes. The analysis of data provides no strong evidence that students who speak English as a second language are handicapped. Access to school libraries in students' pasts is shown possibly to have a positive impact. The study provides some evidence that 
prior computer literacy might contribute to student information literacy. But the ACRL standards assess high-level cognitive processes rather than basic computer skills.

The project provides enough evidence to persevere with the current programme, even with its flaws. If the most effective way to teach information skills is to embed them in subject learning then the findings are ambiguous. The intervention was "embedded" up to a point only. Teaching time was allocated and all students attended as part of the course. However, the lack of involvement by the librarian in the assignment that followed hindered ongoing integration of the information literacy learning into the course.

\section{Conclusion}

The main purpose of this research study was to assess the information literacy intervention in order to gather information on how library information literacy programmes at CPUT might be improved.

The data show that the workshops were effective in terms of improved scores and students' positive feedback. However, there are some questions. The fact that the librarian could not view students' assignments throws doubt over the longer term benefits of the training. The withdrawal of the lecturer revealed a lack of trust in the researcher as an educator and left her unsure of the viability of the project. As research across the world has shown, academics' attitudes provide the biggest challenge to information literacy education.

Any future planning must recognise the need to convince academics of two things:

- The need for information literacy education in UoT education

- Librarians, as information literacy specialists, are educational partners.

Changing academics' attitudes may be beyond the capacity of individual faculty librarians. Support from management inside and outside the Library will be needed. However, the most pressing need is for research evidence for the value of information literacy education that will persuade academics to welcome librarians into their teaching space. 


\section{References}

ALA/ACRL/STS Task Force on Information Literacy for Science and Technology. 2006. Information literacy standards for science and engineering / technology.

Available: www.ala.org/ala/mgrps/divs/acrl/standards/infolitscitech.cfm. [16 July 2010].

Association of College and Research Libraries. 2000. Information literacy competency standards for higher education. Available. http://www.ala.org/ala/mgrps/divs/acrl/standards/standards.pdf [3 August 2006].

Cape Peninsula University of Technology. 2005. Vision and Mission. Available: http://info.cput.ac.za/repository/container/106/VISION_MISSION.pdf [7 July 2006].

Connoway, L S \& Dickey, J. 2010. The digital information seeker: report of the findings from selected OCLC, RIN and JISC user behaviour projects. Bristol: JISC.

Available:

www.jisc.ac.uk/media/documents/.../digitalinformationseekerreport.pdf. [20 July 2010].

De Jager, K \& Nassimbeni, M. 2003. An exploration of the current status of information literacy tuition in South African tertiary institutions and proposals for curriculum design. South African journal of library and information science, 69(2): 108-114.

Du Pré, R. 2009. The place and role of universities of technology in South Africa. Bloemfontein: South African Technology Network.

Engineering Council of South Africa. 2004. Whole qualification standard for Bachelor of Science in Engineering (BSc(Eng)/Bachelors of Engineering (BEng): NQF Level 7. Registered on the National Qualifications Framework: NLRD no. 48694. Document: PE-61. 26 July. Available: http://www.ecsa.co.za/documents/PE-61-r2.pdf. [11 October 2008].

Feldmann, L \& Feldmann, J. 200o. Developing information literacy skills in freshmen engineering technology students. 30 ${ }^{\text {th }}$ ASEE/IEEE Frontiers in Education Conference, October 18 -21, Kansas City, MO. Available: http://fie.engrng.pitt.edu/fie200o/papers/1382.pdf. [30 July 2008].

Gurney, L J \& Wilkes, J. 2008. Creating a library presence in online units. Australian academic \& research libraries, 39 (1): 26-37.

Hugo, A. 2003. From literacy to literacies: preparing higher education in South Africa for the future: perspectives on higher education. South African journal of higher education, 17(2): $46-53$.

Hutcherson, N B. Library jargon: student recognition of terms and concepts used by librarians in the classroom. College \& research libraries, 65(4): 349-354.

King, L. 2007. Information literacy of incoming undergraduate Arts students at the University of the Western Cape: assessment of competencies and proficiencies. PhD Thesis. Bellville: University of the Western Cape.

Kuhlthau, C C. 2004. Seeking meaning: a process approach to library and information services._2nd ed. Westport, CT: Libraries Unlimited.

$$
\text { https://repository.uwc.ac.za/ }
$$


Kuhlthau, C C, Heinström, J \& Todd, R J. 2008. The 'information search process' revisited: is the model still useful? Information research, 13(4). Available http://information.net.ir/13-4/paper355:html. [9 July 2010]

Leckie, G J. and Fullerton, A. 1999. Information literacy in science and engineering undergraduate education: faculty attitudes and pedagogical practices. College and research libraries, 1(Jan): 9-30.

LIS transformation charter ${ }_{2}$ 6th draft. 2009. Pretoria: Department of Arts and Culture and National Council for Library and Information Services. Available: http://www/nlsa.ac.za. [20 October 2009].

Maserumule, M.H. 2005. Designating technikons universities of technology in South Africa: implications for public managementeEducation. African journal of public administration and management, 16(1): 14-27.

McGuinness. C. 2006. What faculty are thinking: exploring the barriers to information literacy development in undergraduate education. Journal of academic librarianship, 32(6): 573-582.

Oberprieler, G, Masters, K \& Gibbs, T. 2005. Information technology and information literacy for first year health sciences students in South Africa: matching early and professional needs. Medical teacher, 27(7): 595-598.

Powell, R R. 1997. Basic research methods for librarians. 3rd ed. Westport: Ablex. Rademeyer, A. 2001. Studente-taal skok: swak prestasies landwyd: 'n derde van alle Tukkies het hulp nodig. Beeld 17 Julie: 1. Available:

http://152.111.1.251/argief/berigte/beeld/2001/o7/17/1/1.html [21 October 2008].

Radia, P \& Stapleton, P. 2007. Unconventional Internet genres and their impact on second language undergraduate students' writing process. Internet and higher education, 11(1): $9-17$.

Roberts, J C \& Bhatt, J. 2007. Innovative approaches to information literacy instruction for engineering undergraduates at Drexel University. European journal of engineeringeEducation,2(3): 243-251.

Ruth, D. W. 1997. Student experience of the University of the Western Cape library: sourcing the problems. South African journal of library and information science, 65(3): 169-180.

Russell C. 2009. A systemic framework for managing e-learning adoption in campus universities: individual strategies in context. Research in learning technology, 17(1): 3-19.

Sayed, Y. 1999. The segregated information highway: information literacy in higher education. Cape Town: University of Cape Town.

Somi, N G \& De Jager, K. 2005. The role of academic libraries in the enhancement of information literacy: a study of Fort Hare Library. South African journal of library and information science, 71(3): 259-267.

Van Wyk, A. 2002. A university bridging course focusing on academic reading and writing skills. Journal for language teaching, 36(3 and 4): 220-232. 
Young, C. 2008. Incorporating undergraduate advising in teaching information literacy: case study for academic librarians as advisors. The journal of academic librarianship. 34(2): 139 - 144.

Yu, F, Sullivan, J \& Woodall, L. 2006. What can students' bibliographies tell us? Evidence based information skills teaching for engineering students. Evidence based library and information practice, 1(2): 12-22. 